\title{
The prevalence of toxoplasmosis among female patients in Al-Hawija and Al-Baiji Districts in Iraq
}

\author{
Mohemid Al-Jebouri*, Mohanad Al-Janabi ${ }^{1}$, Hassan Ismail ${ }^{2}$ \\ ${ }^{1}$ Department of Microbiology, College of Medicine, University of Tikrit, Tikrit, Iraq \\ ${ }^{2}$ Department of Medicine, College of Medicine, University of Tikrit, Tikrit, Iraq \\ Email: profaljebouri@yahoo.com
}

Received 28 November 2012; revised 31 December 2012; accepted 8 January 2013

Copyright (C) 2013 Mohemid Al-Jebouri et al. This is an open access article distributed under the Creative Commons Attribution License, which permits unrestricted use, distribution, and reproduction in any medium, provided the original work is properly cited.

\section{ABSTRACT}

Objectives: Toxoplasma gondii is a ruthless intracellular parasite belonging to Coccidae. Toxoplasmosis is a disease affecting $\mathbf{5 0 0}$ million people worldwide. The seroprevalence varies from $5 \%$ to $90 \%$ depending on geographical location, age, habit of eating, raw meat or unwashed fruit and vegetables, and general level of hygiene. The objective of the current study was to assess the prevalence of this parasitic disease which lately seems to be elevated generally in Iraq and particularly in the middle and northern Iraq. A prospective study was carried out on females which attended public hospitals complaining of abortion and/ or infertility during 2009. Methods: We collected blood samples from the female patients to detect the presence of specific antibodies of Toxoplasma gondii utilizing direct agglutination test which was compared with ELISA techniques for evaluations of their testing sensitivity. The history of all patients was taken particularly abortion and marriage periods with and/ or without children with the family. Results: Direct latex agglutination test and ELISA methodology gave almost the same results when both were utilized for the detection of the toxoplasmosis in the sera of the women examined. A high frequency of toxoplasmosis incidence was seen among women with one abortion group which happen during their marital life. Conclusions: It was concluded that the high prevalence of toxoplasmosis among the investigated high risk women at Al-Hawija and at Al-Baiji districts is due to many risk factors including age, number of deliveries, contact with host animals. This disease was elevated after Iraq occupation with a frequency of infection more than $\mathbf{4 0 \%}$ compared to eighties of Iraqi life which was the frequency of the infected women with toxoplas-

"Corresponding author. mosis which did not exceed $2 \%$ of the women tested at that time by our laboratories.

Keywords: Toxoplasmosis; Females; Abortion; Infertility; Iraq

\section{INTRODUCTION}

Toxoplasma gondii is a ruthless intracellular parasite belonging to Coccidae. T. gondii occurs in three forms: tachyzoites, bradyzoites (in tissues), and sporozoites. The parasite locates in the brain, heart, lungs, and most frequently in the lymph nodes. Toxoplasmosis is a disease affecting 500 million people worldwide. The seroprevalence varies from $5 \%$ to $90 \%$ depending on geographical location, age, habit of eating raw meat or unwashed fruit and vegetables, and general level of hygiene. The incidence of infections is higher in warmer and humid climate and increases with age. The disease can be congenital or acquired [1-4]. The parasite after invading the human body multiplies inside the cell, causing damage to the reticuloendothelial system. Rapid multiplication of the parasite and formation of the so-called pseudocysts are characteristics of the acute phase of invasion [5].

In parasitic invasions, an increase is observed in the production of IgE antibodies, especially in helminth infections. This defect results from disturbances in the regulation of antibody production by Th cells, which promotes local inflammatory reaction. Via release of mediators from mast cells IgE participates in the reaction of antibody dependent cellular cytotoxicity (ADCC). Cytotoxic activity of eosinophils is increased under the influence of cytokines (TNF- $\alpha$ and IL-5) released by mast cells, lymphocytes, and macrophages [6]. Th2 lymphocytes synthesize specific cytokines (IL-4, IL-5, IL-6, IL10, IL-13, and IL-14), which play a major role in the pathogenesis of parasitic diseases. IL-5 is the major cy- 
tokine responsible for the increase in the eosinophil population in parasitoses, whereas IL-6 stimulates production of antibodies and exerts a proinflammatory effect by stimulating the generation of acute phase proteins. IL-10 and IL-12 control the type of the immune response. The former inhibits cytokine synthesis and by blocking the production of IL- 6 and TNF- $\alpha$ causes an advantage of the response occurring with Th2 involvement and B cell activation. However, IL-12 facilitates formation of a Th1 type response [7-10].

\section{MATERIALS AND METHODS}

Blood samples were collected from 285 women (150 from Al-Hawija and 80 from Al-Baiji subjects) with average number of abortions (1 - 3) during 2009. The final diagnosis of toxoplasmosis was determined by the presence of IgM anti-Toxoplasma gondii ( $>1.252$ UI, positive cut-off > 0.65; ELISA Biokit, Toxo IgM, Biomieux, Spain) [11]. Direct latex agglutination test was done by utilizing Toxocell (Toxocell latex, Barcellona, Spain); this technique was used for direct detection of Toxoplasma gondii antibodies according to the manufacturer's in structions.

\section{RESULTS}

Direct latex agglutination test and ELISA methodology gave almost the same results when both were utilized for the detection of the toxoplasmosis in the sera of the women examined. The statistical analysis of the data showed no significant differences between the results of the both methods used; the positivity of the tests was 89 and 100 percents respectively (Table $\mathbf{1}$ ).

Table 2 shows that women in Al-Hawija district were under risk of catching toxoplasmosis more than those living in Al-Baiji district and more than $50 \%$ of them were infected with this parasite.

A high frequency of toxoplasmosis incidence was seen among women with one abortion group which happen during their marital life (Table 3). Direct latex agglutination test and ELISA methodology gave almost the same results when both were utilized for the detection of the toxoplasmosis in the sera of the women examined, i.e after marriage tested (Table 4). Table 4 shows that Toxoplasma gondii can be attack any women.

Table 1. Comparison between two serological diagnostic methods of toxoplasmosis among women.

\begin{tabular}{ccc}
\hline Method used & No. patients tested & No. (\%) of patients positive \\
\hline Direct agglutination test & 121 & $108(89)$ \\
ELISA (anti-toxoplasma IgM) & 121 & $121(100)$ \\
\hline
\end{tabular}

Table 2. The prevalence of toxoplasmosis among patients of Al-Hawija and Al-Baiji districts.

\begin{tabular}{cccc}
\hline District & No. patients examined & No. of patients with toxoplasmosis & $\%$ positive \\
\hline Al-Hawija & 150 & 80 & $53 \%$ \\
Al-Baiji & 135 & 41 & $30 \%$ \\
Overall & 285 & 121 & $42 \%$ \\
\hline
\end{tabular}

Table 3. The rate of abortions in women infected with toxoplasmosis.

\begin{tabular}{ccccc}
\hline \multirow{2}{*}{ No. of abortion } & \multicolumn{3}{c}{ No. of patients tested } & Total \\
\cline { 2 - 4 } & Al-Hawija & Al-Baiji & 26 \\
1 & 16 & 10 & 37 \\
2 & 15 & 22 & 31 \\
3 & 3 & 20 & 27 \\
Total & 7 & 80 & 121 \\
\hline
\end{tabular}

Table 4. Number of children possessed by women tested for toxoplasmosis.

\begin{tabular}{cccccccc}
\hline District & \multicolumn{9}{c}{ No. of babies possessed } & Total \\
\cline { 2 - 6 } & $\mathbf{0}$ & 1 & 2 & 3 & 4 & 80 \\
Al-Hawija & 30 & 22 & 18 & 7 & 3 & 41 \\
Al-Baiji & 18 & 11 & 7 & 2 & 3 & 6 \\
Total & 48 & 33 & 25 & 9 & 6 & 121 \\
\hline
\end{tabular}




\section{DISCUSSION}

Routine serologic diagnosis of toxoplasmosis provides high sensitivity, but specifity varies depending on the test used [11]. The present attempt showed that there was no significant difference in the data collected when direct latex agglutination and ELISA tests utilized and compared (Table 1). The same conclusion was reported by Anoine et al [12]. The present findings can make the survey studies on toxoplasmosis distribution especially in the third world countries easier and cheaper to be carried out particularly in the time of high incidence of the disease. However, it was shown that the high number of toxoplasmosis cases were recorded among females with seen among families with one baby that being already delivered (Table 3). However, $T$. gondii infection in human may occur vertically by tachyzoites that are passed to the foetus via the placenta, or horizontal transmission which may involve three life cycle stages i.e. Ingesting sporulated oocysts from cats or ingesting tissue cysts in raw or under cooked meat or tachyzoites in blood products or primary offal (viscera) of many different animals, tissue transplants and unpasteurized milk [13]. Furthermore, the women examined might be already infected with disease before marriage and she might be chronic carrier of the parasite concerned. The present report showed that $\mathrm{Al}$-Hawija district is more contaminated by the organism compared to Al-Baiji area and this might be because that $\mathrm{Al}$-Hawija area is a well known agricultural area in Iraq, so there are a large number of animal keepers in the area and consequently the possible transmission of the parasite is suspected due to large opportunity of contacts with animal which might be infected with toxoplasmosis [13]. Morever, in the present study, the seroprevalence of $T$. gondii IgG and IgM among non-pregnant women was higher than pregnant group as shown in Table 4. In contrast, pregnant women were mostly under risk of catching toxoplasmosis as concluded elsewhere [14].

It was concluded that the high prevalence of toxoplasmosis among the investigated high risk women at AlHawija and at Al-Baiji districts is due to many risk factors including age, number of deliveries, contact with host animals (small ruminants), contact with uncooked meat, drinking raw sheep or goat milk as well as neglegable studies on the disease concerned, bad health education, no efficient medication, no surveys and possible environmental pollution with the organisms due to situations of sanctions and series of wars that attacked the country as far as this disease was elevated after Iraq occupation with a frequency of infection more than $40 \%$ compared to eighties of Iraqi life which was the frequency of the infected women with toxoplasmosis did not exceed $2 \%$ of the women tested at that time by our laboratories.

\section{CONCLUSION}

This disease was elevated after Iraq occupation with a frequency of infection more than $40 \%$ compared to eighties of Iraqi life which was the frequency of the infected women with toxoplasmosis which did not exceed $2 \%$ of the women tested at that time by our laboratories. Possible environmental pollution with the organisms due to situations of sanctions and series of wars that attacked the country as far as this disease was elevated after Iraq occupation.

\section{REFERENCES}

[1] Evering, T. and Weiss, L.M. (2006) The immunology of parasite infections in immunocompromised hosts. Parasite Immunolology, 28, 549-565.

[2] Hegab, S.M. and Al-Mutawa, S.A. (2003) Immunopathogenesis of toxoplasmosis. Clin Experimental Medicine, 3, 84-105. doi:10.1007/s10238-003-0011-2

[3] Lappalainen, M. and Hedman, K. (2004) Serodiagnosis of toxoplasmosis. The impact of measurement of IgG avidity. Annalidell'Istituto Superiore di Sanita, 40, 81-88.

[4] Suzuki, L.M., Rocha, R.J. and Rossi, C.L. (2001) Evaluation of serological markers for the immunodiagnosis of acute acquired toxoplasmosis. Journal of Medical Microbiolology, 50, 62-70.

[5] Biesiada, G., Kalinowska-Nowak, A., Czepiel, J. and Mach. T. (2006) Toxoplasmosis-Epidemiology, clinical manifestation and infection in pregnant women. Przegląd Lekarski, 63, 97-99.

[6] Nickdel, M.B., Roberts, F., Brombacher, F., Alexander, J. and Roberts C.W. (2001) Counter-protective role for interleukin-5 during acute Toxoplasma gondii infection. Infection and Immunity, 2, 1044-1052. doi:10.1128/IAI.69.2.1044-1052.2001

[7] Lang, C., Gross, U. and Lüder, C.G. (2007) Subversion of innate and adaptive immune responses by Toxoplasma gondii. Parasitolological Research, 100, 191-203.

[8] Romagnani, S. (1996) Understanding the role of Th1/Th2 cells in infection. Trends in Microbiolology, 4, 470-473. doi:10.1016/S0966-842X(97)82906-X

[9] Vilcek, J. and Lee, T.H. (1991) Tumor necrosis factor: New insights into the molecular mechanisms of its multiple actions. Journal of Biological Chemistry, 266, 73137316.

[10] Zaccone, P., Fehervari, Z., Phillips, J.M., Dunne, D.W. and Cooke, A. (2006) Parasitic worms and inflammatory diseases. Parasite Immunolology, 28, 515-523. doi:10.1111/j.1365-3024.2006.00879.x

[11] Neves, E.S., Bicudo, L.N., Curi, A.L., Carrega, L.E., Bueno, W.F., Ferreira, R.G., Amendoeira, M.R., Benchimo, L.E. and Fernandes, O. (2009) Acute acquired toxoplasmosis: Clinical-laboratorial aspects and ophthalmologic evaluation in a cohort of immunocompetent patients. Memórias do Instituto Oswaldo Cruz, 104, 393-396.

[12] Antoine, B., Eskild, P., Roger, S., Genevieve, C., Ruth, G. 
and Richid, S.L. (2010) Survey of european programme for the epidemiological surveillance of congenital toxoplasmosis. Euro Surveillance, Author Manuscript.

[13] Ghoneim, N.H., Shalaby, S.I., Hassanian, N.A., Zeadan, G.S.G. and Soliman, Y.A. (2009) Detection of genomic Toxoplasma gondii DNA and anti-toxoplasma antibodies in high risk women and contact animals. Global Veteri- naria, 3, 395-400.

[14] Han, K., Shin, D.W., Lee, T.Y. and Lee, Y.H. (2008) Seroprevalence of Toxoplasma gondii infection and risk factors associated with seropositivity of pregnant women in Korea. Journal of Parasitolology, 94, 963-965. doi:10.1645/GE-1435.1 